\title{
Caudal and Penile Blocks Demonstrate Similar Reliability and Efficacy in Pediatric Patients Undergoing Circumcision: A Meta-Analysis
}

\author{
Kiran Malik ${ }^{1}$, Ronald S. Chamberlain ${ }^{1,2,3^{*}}$ \\ ${ }^{1}$ Saint George's University School of Medicine, Grenada, West Indies \\ ${ }^{2}$ Department of Surgery, Saint Barnabas Medical Center, Livingston, USA \\ ${ }^{3}$ Department of Surgery, New Jersey Medical School, Rutgers University, Newark, USA \\ Email: *rchamberlain@barnabashealth.org
}

Received 30 January 2016; accepted 23 May 2016; published 26 May 2016

Copyright @ 2016 by authors and Scientific Research Publishing Inc.

This work is licensed under the Creative Commons Attribution International License (CC BY). http://creativecommons.org/licenses/by/4.0/

(c) (i) Open Access

\section{Abstract}

Purpose: Circumcision is one of the most common surgeries performed in the pediatric population. Multiple regional analgesic techniques, including caudal (CB) and penile block (PB), have championed as offering optimal analgesia for circumcision in the post-neonatal pediatric population without clear consensus. This meta-analysis sought to investigate CB and PB's analgesic efficacy and the impact on postoperative analgesic requirements in pediatric circumcisions. Methods: A comprehensive literature search of PubMed, Google Scholar, and Cochrane Library (1966-2016) was completed to identify all published randomized control trials (RCTs). Keywords searched included "circumcision", "caudal block", "penile block", and "analgesia". Inclusion criteria were limited to the comparison of PB versus CB in children less than 18 years of age and its efficacy towards circumcision. The efficacy, time to first additive analgesia, time to first micturition, duration of prolonged motor blockade, incidence of vomiting, and length of stay were analyzed. Results: 9 RCTs involving 574 children $(\mathrm{N}=287$ in $\mathrm{CB}$ and $\mathrm{PB})$ were included. No differences in analgesic efficacy (relative risk $(R R)=0.983,95 \%$ confidence interval $(C I)=0.95$ to $1.02 ; p=0.328$ ) or time to first additive analgesia were observed (standardized difference in mean (SDM) $=0.438,95 \% \mathrm{CI}$ $=-0.04$ to $0.92 ; p=0.073)$. Time to first micturition $(\mathrm{SDM}=0.680,95 \% \mathrm{CI}=0.40$ to $0.96 ; p<0.001)$ and motor block duration $(\mathrm{SDM}=0.707,95 \% \mathrm{CI}=0.19$ to $1.22 ; p=0.007$ ) were significantly prolonged in patients receiving CB. No differences were observed between groups in regards to the incidence of vomiting $(\mathrm{RR}=1.56,95 \% \mathrm{CI}=0.91$ to $2.67 ; p=0.107)$ and length of stay $(\mathrm{SDM}=0.741$, $95 \% \mathrm{CI}=-0.05$ to $1.53 ; p=0.066$ ). Conclusion: $\mathrm{CB}$ and $\mathrm{PB}$ offer similar analgesic success rates for pediatric patients (age 18 months to 16 years) undergoing circumcision. CB is associated with a

*Corresponding author.

How to cite this paper: Malik, K. and Chamberlain, R.S. (2016) Caudal and Penile Blocks Demonstrate Similar Reliability and Efficacy in Pediatric Patients Undergoing Circumcision: A Meta-Analysis. International Journal of Clinical Medicine, 7, 309319. http://dx.doi.org/10.4236/ijcm.2016.75033 
trend towards longer duration of analgesia, but is associated with prolonged urinary retention and delayed ambulation. CB use is recommended in non-ambulatory children, whereas PB is recommended in ambulatory children.

\section{Keywords}

\section{Circumcision, Caudal Block, Penile Block}

\section{Introduction}

Male circumcision is the most common pediatric surgical procedure performed globally [1] [2]. Worldwide regional prevalence varies significantly due to social, cultural, and religious influences [3]. Circumcision is nearly universal in northern Africa and Muslim Asian countries; whereas prevalence is approximately 15\% in sub-Saharan Africa and the United Kingdom [3]. A 2010 report by the Centers for Disease and Prevention (CDC) reported $80 \%$ of males between the ages of 14 - 59 years were circumcised in the United States (US) [4] [5]. The CDC estimates that only 58.3\% of circumcisions in the US occur during the initial birth hospitalization, resulting in a significant proportion of male children requiring circumcisions as toddlers or adolescents [6].

Reports of medical benefits have contributed to the high prevalence rates of circumcision in the US. Morris et al. (2014) reported that over the course of a circumcised male's lifetime, the benefits of circumcision exceed the risks by a ratio of 100:1 [5]. The only risks associated with circumcision were surgical complications such as wound infections, whereas the benefits included reduction in urinary tract infections, pyelonephritis, candidiasis, and sexually transmitted infections [5]. The reduced risk of infections is attributed to decreased accumulation of bacteria on the head of penis [5] [7]. Circumcision also reduces the transmission of viruses like human immunodeficiency virus (HIV) and human papilloma virus (HPV) [5]. Additionally, a recent systematic review by Morris and Krieger (2013) involving 19,542 uncircumcised and 20,931 circumcised men demonstratedno adverse effects of circumcision on sexual function, sensitivity, or sexual satisfaction [8]-[10].

Inadequate pain management during circumcision has been associated with altered sensory processing resulting in heightened response to future painful stimuli [11]-[14]. Taddio et al. (1997) reported immunization associated pain increased in circumcised children compared touncircumcised children [14]. Insufficient analgesiawith a placebo during circumcisions was associated with increased future pain sensation in contrast to analgesia with topical anesthetic [14]. Thus adequate analgesia is imperative in circumcision. The most efficient analgesic during circumcision is regional anesthesia, namely caudal (CB) and penile blocks (PB) [15] [16].

CB is a regional anesthesia that is most often used for infra-umbilical incisions, particularly inguinal hernia repair and circumcision [17]. This technique initially uses general anesthesia to sedate the patient and facilitate local anesthetic placement into the caudal epidural space. A study by Shanthanna et al. (2014) reported that landmark ambiguity resulted in up to a $20 \%$ technical failure requiring additional postoperative analgesia [18]. Similar to CB, PB is also commonly performed with general anesthesia as it facilitates block placement. There are two types of PB: 1) dorsal nerve penile block which injects a local anesthetic below the pubic bone at the base of the penis and 2) a subcutaneous ring block which injects local anesthetic around the base of the penile shaft [16] [19].

Controversy over the efficacy of these two techniques exists, as some studies have suggesteda decreased efficacy and increased block failure rate for CB [18] [20] [21]. A Cochrane systematic review (2008) which included 4 studies concluded that there wereno differences in the success rate or analgesic duration between $\mathrm{CB}$ and $\mathrm{PB}$, thoughCB resulted in a longer duration of motor block [22]. This meta-analysis updates the previous Cochranesystematic review (2008) byincludingfive additional randomized control trials (RCT)in an attempt to more precisely define the optimal anesthetic technique for non-neonatal circumcisions.

\section{Materials and Methods}

\subsection{Study Selection}

A comprehensive search of all published RCTs comparing CB and PB during circumcision was conducted using PubMed, Google Scholar, and Cochrane Central Registry of Controlled Trials (1966-2015). Additional citations 
were searched using references retrieved from prior publications (Figure 1). The last search was conducted on January 28, 2016 and only articles conducted in English were considered. Keywords searched included all combinations of "caudal block", "penile block", and "analgesia" in circumcision. The inclusion criteria were limited to RCTs in circumcision, pediatric population ( $<18$ years), comparison of PB and CB, and availability of the event efficacy with sample size. In case of duplicate publications, only the most recent and updated report of the clinical trial was included. The study is compliant with PRISMA guidelines.

\subsection{Data Extraction}

Articles retrieved from this search were assessed for eligibility and data pertaining to patients, intervention, comparison groups, outcomes, and methodology were abstracted. The primary clinical outcome of interest wasefficacy, defined as number of patientsrequiring no additional pain relief within the first two hours of surgery. Secondary outcomes included time to first additive analgesia, time to first post-circumcision micturition, duration of prolonged motor blockade, risk of vomiting, and length of stay.

\subsection{Statistical Analysis}

For each trial, relative risk (RR) with a 95\% confidence interval (CI) for efficacy and vomiting were calculated. Standard difference in mean (SDM) with 95\% CI were calculated for time to first additive analgesia, time to first micturition post-circumcision, and duration of motor blockade. Meta-analysis of the pooled data was performed using the Comparative Meta-Analysis software Version 3 (Biostat, Englewood, NJ). For individual studies reporting zero events in any group, a continuity correction factor of 0.5 was adopted to calculate the RR and variance. In the event of zero events in both groups, the RR was not calculable and the study was excluded from the meta-analysis. Both the fixed effects model and random-effects model were considered, depending on the heterogeneity of the included studies. To assess the heterogeneity between studies, both Cochrane's Q statistic

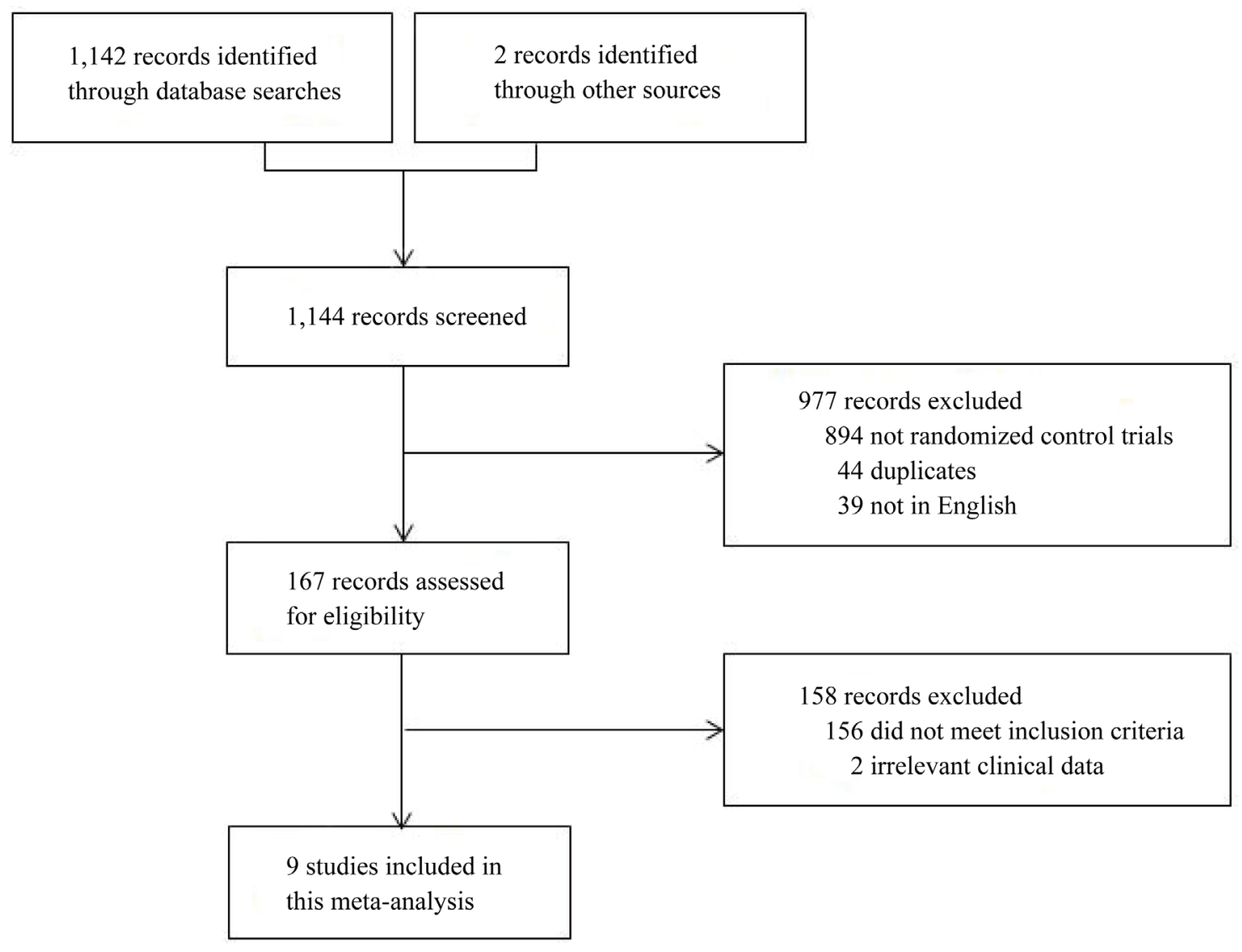

Figure 1. CONSORT diagram of the study selection process. 
and $\mathrm{I}^{2}$ statistic were used. Heterogeneity was considered statistically significant when $p<0.05$ or $\mathrm{I}^{2}>50$. If heterogeneity was observed, data was analyzed using a random-effects model. In the absence of heterogeneity, a fixed-effects model was assumed.

In the cases of trials reporting results as a median and range, mean and standard deviation was estimated based on Hozo et al. (2005) and Bland (2015) [23] [24]. Outliers as mentioned in the original RCT were not included in the analysis. For all the outcomes, publication bias was first evaluated using a funnel plot, and further evaluated with Egger's and Begg's tests. Subgroup analysis was performed based on the anestheticused, bupivacaine orlevobupivacaine. A two-tailed $p$-value of $<0.05$ was considered statistically significant.

\section{Results}

\subsection{Demographic Characteristics of the Studies}

A total of nine RCTs were identified involving 574 children, age 18 months to 16 years (Table 1). The children were equally divided with 287 patients in each group receiving either CB or PB for circumcision. Seven of the nine trials used bupivacaine, while two of the nine trials used levobupivacaine.

Table 1. Characteristics of the randomized control trials comparing caudal block and penile block in circumcision (19662015).

\begin{tabular}{|c|c|c|c|c|c|c|c|c|c|c|c|}
\hline $\begin{array}{l}\text { Author, } \\
\text { year }\end{array}$ & $\mathbf{N}$ & $\begin{array}{l}\text { Inclusion } \\
\text { criteria } \\
\text { age range } \\
\text { (yrs) }\end{array}$ & $\begin{array}{l}\text { Mean } \\
\text { age } \\
\text { (yrs) } \\
\text { CB } \\
\text { group }\end{array}$ & $\begin{array}{l}\text { Mean } \\
\text { age } \\
\text { (yrs) } \\
\text { PB } \\
\text { group }\end{array}$ & $\begin{array}{c}\text { Mean } \\
\text { weight } \\
\text { (kg) } \\
\text { CB } \\
\text { group }\end{array}$ & $\begin{array}{c}\text { Mean } \\
\text { weight } \\
\text { (kg) } \\
\text { PB } \\
\text { group }\end{array}$ & $\begin{array}{l}\text { Medication dose } \\
\text { CB group }\end{array}$ & $\begin{array}{l}\text { Medication dose } \\
\text { PB group }\end{array}$ & $\begin{array}{c}\text { Time to } \\
\mathbf{1}^{\text {st }} \\
\text { additive } \\
\text { analgesia } \\
\text { (min) } \\
\text { CB group } \\
\text { (mean } \pm \\
\text { SD) }\end{array}$ & $\begin{array}{c}\text { Time to } 1^{\text {st }} \\
\text { additive } \\
\text { analgesia } \\
\text { (min) PB } \\
\text { group } \\
\text { (mean } \pm \\
\text { SD) }\end{array}$ & $\begin{array}{l}\text { F/U } \\
\text { (hrs) }\end{array}$ \\
\hline $\begin{array}{l}\text { Yeoman et } \\
\text { al., } 1983\end{array}$ & 38 & 1.5 to 12 & $\begin{array}{c}6.25 \pm \\
3.2\end{array}$ & $\begin{array}{c}6.5 \pm \\
3.2\end{array}$ & 22.3 & 23.2 & $\begin{array}{l}0.5 \% \text { bupivacaine } \\
(1 \mathrm{~mL} / \mathrm{yr}+2 \mathrm{~mL})\end{array}$ & $\begin{array}{l}0.5 \% \text { bupivacaine } \\
\quad(1 \mathrm{~mL} / 3 \mathrm{yr})\end{array}$ & - & - & 7 \\
\hline $\begin{array}{c}\text { Vater \& } \\
\text { Wandless, } \\
1985\end{array}$ & 50 & 1 to 13 & $\begin{array}{c}5.6 \pm \\
3.4\end{array}$ & $\begin{array}{c}4.6 \pm \\
2.9\end{array}$ & $\begin{array}{c}20.3 \pm \\
7.3\end{array}$ & $\begin{array}{c}18.1 \pm \\
6.2\end{array}$ & $\begin{array}{c}0.25 \% \\
\text { bupivacaine } \\
(0.5 \mathrm{~mL} / \mathrm{kg})\end{array}$ & $\begin{array}{l}\text { 0.5\% bupivacaine } \\
\text { (1-5 yrs - } 3 \mathrm{~mL} ; \\
6-12 \text { yrs }-4 \mathrm{~mL})\end{array}$ & $\begin{array}{l}313 \pm \\
183.3\end{array}$ & $\begin{array}{c}256.4 \pm \\
177.6\end{array}$ & 24 \\
\hline $\begin{array}{c}\text { Irwin \& } \\
\text { Chang, } \\
1996\end{array}$ & 50 & 2 to 12 & $\begin{array}{c}5.1 \pm \\
2.1\end{array}$ & $\begin{array}{c}6.4 \pm \\
2.9\end{array}$ & $\begin{array}{c}18.9 \pm \\
5.9\end{array}$ & $\begin{array}{c}22.3 \pm \\
9.4\end{array}$ & $\begin{array}{c}0.25 \% \\
\text { bupivacaine } \\
(0.75 \mathrm{~mL} / \mathrm{kg})\end{array}$ & $\begin{array}{l}\text { 0.5\% bupivacaine } \\
\quad(1-2 \mathrm{~mL})\end{array}$ & - & - & 24 \\
\hline $\begin{array}{l}\text { Mak et al., } \\
2001\end{array}$ & 126 & 1 to 12 & $\begin{array}{c}6.5 \pm \\
2.9\end{array}$ & $\begin{array}{c}6.5 \pm \\
3.0\end{array}$ & $\begin{array}{c}24.6 \pm \\
9.4\end{array}$ & $\begin{array}{c}23.3 \pm \\
8.0\end{array}$ & $\begin{array}{c}0.25 \% \\
\text { bupivacaine } \\
(0.5 \mathrm{~mL} / \mathrm{kg})\end{array}$ & $\begin{array}{c}\text { 0.5\% bupivacaine } \\
\text { (<15 kg - } 2 \mathrm{~mL} ; 15 \text { - } \\
24 \mathrm{~kg}-2.5 \mathrm{~mL} ; 25 \text { - } \\
30 \mathrm{~kg}-3 \mathrm{~mL} ; 31 \text { - } \\
40 \mathrm{~kg}-3.5 \mathrm{~mL} ;>40 \\
\text { kg - } 4 \mathrm{~mL})\end{array}$ & $\begin{array}{l}354 \pm \\
143.8\end{array}$ & $\begin{array}{l}366 \pm \\
173.2\end{array}$ & 96 \\
\hline $\begin{array}{l}\text { Gautlett, } \\
2003\end{array}$ & 60 & 1 to 10 & $\begin{array}{c}5.09 \pm \\
2.32\end{array}$ & $\begin{array}{c}5.47 \pm \\
2.43\end{array}$ & $\begin{array}{c}20.9 \pm \\
6.0\end{array}$ & $\begin{array}{c}22.1 \pm \\
6.9\end{array}$ & $\begin{array}{c}0.15 \% \\
\text { bupivacaine (0.5 } \\
\mathrm{mL} / \mathrm{kg}), \mathrm{ketamine} \\
(0.5 \mathrm{mg} / \mathrm{kg})\end{array}$ & $\begin{array}{c}0.5 \% \text { bupivacaine } \\
\text { (3 - } 5 \mathrm{~mL} \text { by age }+ \\
1 \mathrm{~mL} \text { subQ) }\end{array}$ & - & - & 24 \\
\hline $\begin{array}{l}\text { Weksler et } \\
\text { al., } 2005\end{array}$ & 100 & 3 to 8 & $5 \pm 2$ & $5 \pm 2$ & $20 \pm 4$ & $20 \pm 4$ & $\begin{array}{c}0.25 \% \\
\text { bupivacaine } \\
(1 \mathrm{~mL} / \mathrm{kg})\end{array}$ & $\begin{array}{l}\text { 0.5\% bupivacaine } \\
\quad(0.3 \mathrm{~mL} / \mathrm{kg})\end{array}$ & - & - & 24 \\
\hline $\begin{array}{l}\text { Margetts } \\
\text { et al., } \\
2008\end{array}$ & 40 & 1.5 to 16 & $\begin{array}{c}7.8 \pm \\
1.7\end{array}$ & $\begin{array}{c}7.9 \pm \\
1.3\end{array}$ & - & - & $\begin{array}{c}0.25 \% \\
\text { bupivacaine (0.5 } \\
\mathrm{mL} / \mathrm{kg}), \mathrm{ketamine} \\
(0.5 \mathrm{mg} / \mathrm{kg})\end{array}$ & $\begin{array}{l}\text { 0.5\% bupivacaine } \\
(0.25 \mathrm{~mL} / \mathrm{kg})\end{array}$ & $\begin{array}{c}485.8 \pm \\
124.9\end{array}$ & $\begin{array}{c}361.3 \pm \\
183.1\end{array}$ & 24 \\
\hline $\begin{array}{l}\text { Beyaz, } \\
2011\end{array}$ & 50 & 3 to 12 & $\begin{array}{c}7.4 \pm \\
3.1\end{array}$ & $\begin{array}{c}8.5 \pm \\
3.5\end{array}$ & $\begin{array}{l}23.4 \pm \\
8.6\end{array}$ & $\begin{array}{c}29.4 \\
\pm 11.3\end{array}$ & $\begin{array}{c}0.25 \% \\
\text { levo-bupivacaine } \\
(0.5 \mathrm{~mL} / \mathrm{kg})\end{array}$ & $\begin{array}{c}0.25 \% \\
\text { levo-bupivacaine } \\
(0.5 \mathrm{~mL} / \mathrm{kg})\end{array}$ & $354 \pm 15$ & $352 \pm 18$ & 6 \\
\hline $\begin{array}{l}\text { Kazak et } \\
\text { al., } 2012\end{array}$ & 60 & 2 to 10 & $6 \pm 3$ & $7 \pm 2$ & $23 \pm 9$ & $26 \pm 6$ & $\begin{array}{c}0.25 \% \\
\text { levo-bupivacaine } \\
(1 \mathrm{mg} / \mathrm{kg})\end{array}$ & $\begin{array}{c}0.25 \% \\
\text { levo-bupivacaine } \\
(1 \mathrm{mg} / \mathrm{kg})\end{array}$ & $458 \pm 73$ & $376 \pm 68$ & 24 \\
\hline
\end{tabular}

Abbreviations: CB, caudal block; F/U, follow up; hrs, hours; kg, kilograms; mg, milligram; min, minutes; mL, milliliter; N, number of patients included; PB, penile block; SD, standard deviation; subQ, subcutaneous; yrs, years. 


\subsection{Efficacy of CB and PB in Circumcision}

All nine RCTs reportedhigh levels of efficacy for both types of anesthetic block (Figure 2) [15] [16] [20] [21] [25]-[29]. Similar numbers of children had successful blocks with CB and PB (97\% and 98\% respectively; $\mathrm{N}=$ 287 in both arms). Individually, two of the nine trials reported equal efficacy, four studies reported increased efficacy following PB, and three studies reported increased efficacy after CB; however all studies failed to reach statistical significance. There was no significant heterogeneity between trials $\left(p=0.353, \mathrm{I}^{2}=9.971\right)$ and a fixed-effects model was utilized. Meta-analysis revealed no difference in analgesic efficacy between CB and PB $(\mathrm{RR}=0.983,95 \% \mathrm{CI}=0.95$ to $1.02 ; p=0.328)$.

\subsection{Time to First Additive Analgesia for CB and PB in Circumcision}

Time to first additive analgesia was reported in five trials involving 156 children in the CB group and 157 in the PB group (Figure 3) [15] [16] [21] [26] [29]. Individually, fourtrials reported longer analgesic duration after CB, two of which reached statistical significance. One of the statistically significant trials used ketamine as an adjuvant to CB [29]. One trial reported equivalent duration of analgesic duration between CB and PB. There was

\begin{tabular}{|c|c|c|c|c|c|c|c|c|}
\hline \multirow[t]{2}{*}{ Author,year } & \multirow[t]{2}{*}{ Medcation } & \multirow[b]{2}{*}{$\begin{array}{l}\text { Risk } \\
\text { ratio }\end{array}$} & \multicolumn{3}{|c|}{ Statlstics for eech study } & \multirow[b]{2}{*}{$\begin{array}{c}\text { Relative } \\
\text { weight }\end{array}$} & & \multirow[t]{2}{*}{ Risk ratio and $95 \% \mathrm{Cl}$} \\
\hline & & & $\begin{array}{c}\text { Lower } \\
\text { limit }\end{array}$ & $\begin{array}{l}\text { Upper } \\
\text { limit }\end{array}$ & p-Value & & & \\
\hline Yeomen,1983 & bupivecaine & 1.054 & 0.913 & 1.216 & 0.471 & 5.95 & & - \\
\hline Vater,1985 & bupivecaine & 1.043 & 0.907 & 1.201 & 0.553 & 6.18 & & \\
\hline Lrwin,1996 & bupivecaine & 1.085 & 0.947 & 1.244 & 0.241 & 6.56 & & \\
\hline Mak,2001 & bupivecaine & 0.989 & 0.918 & 1.022 & 0.245 & 41.91 & & \\
\hline Gauntlet,2003 & bupivecaine & 0.902 & 0.789 & 1.030 & 0.128 & 6.86 & & \\
\hline Welsler,2005 & bupivecaine & 0.980 & 0.897 & 1.028 & 0.244 & 26.37 & & \\
\hline \multirow[t]{4}{*}{ Beyez,2011 } & levoloupivecaine & 1,043 & 0.907 & 1.201 & 0.553 & 6.18 & & \\
\hline & & 0.983 & 0.949 & 1.018 & 0.328 & & & \\
\hline & & & & & & & 0.5 & 1 \\
\hline & & & & & & & \multicolumn{2}{|c|}{ Favors Penile Block Favors Caudal Block } \\
\hline
\end{tabular}

Abbreviation:CI,confidence interval

Figure 2. Forest plot evaluating the relative risk of caudal and penile block efficacy in circumcision for pediatric patients.

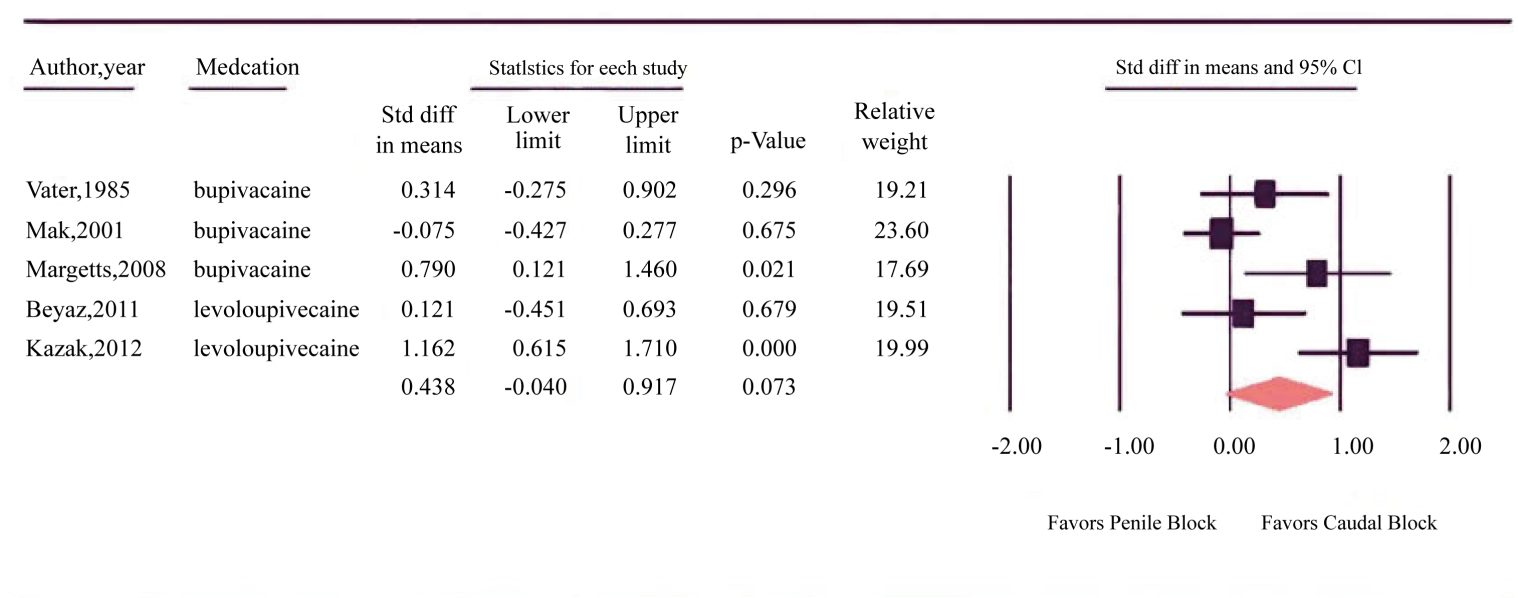

Abbreviation:CI,confidence interval; diff,difference;Std, standard.

Figure 3. Forest plot evaluating the standardized difference in mean for the time to first additive analgesia with caudal and penile block in pediatric circumcision. 
significant heterogeneity between trials $\left(p=0.003, \mathrm{I}^{2}=75.469\right)$ and a random-effects model was assumed. Meta-analysis revealed a trend towards prolonged analgesia in CB though results failed to reach statistical significance $(\mathrm{SDM}=0.438,95 \% \mathrm{CI}=-0.04$ to $0.92 ; p=0.073)$.

\subsection{Time to First Micturition for CB and PB in Circumcision}

Time to first micturition was reported in four trials involving 106 patients in each group (Figure 4) [16] [20] [21] [27]. All four trials reported longer time tomicturition after CB and two trials reached statistical significance. There was no significant heterogeneity between trials $\left(p=0.208, \mathrm{I}^{2}=34.016\right)$ and a fixed-effects model was assumed. Meta-analysis revealedlonger time to micturition after CB (SDM $=0.680,95 \% \mathrm{CI}=0.40$ to $0.96 ; p<$ $0.001)$.

\subsection{Duration of Motor Blockade for CB and PB in Circumcision}

Duration of prolonged motor blockade was reported in four trials involving 99 patients in the CB group and 94 patients in the PB group (Figure 5) [16] [20] [21] [29]. Three of the four studies identified a statistically significant prolonged motor blockade after $\mathrm{CB}$, whereas one study reported equivalent duration of motor block in $\mathrm{CB}$ and PB. Overall, there was significant heterogeneity between trials $\left(p=0.028, \mathrm{I}^{2}=67.151\right)$ and a random-effects model was assumed. Meta-analysis revealed a longer motor block among patients receiving CB (SDM $=0.707$, $95 \%$ CI $=0.19$ to $1.22 ; p=0.007$ ).

\subsection{Vomiting in CB and PB in Circumcision}

Incidence of vomiting was reported in all nine trials but did not include children with failed blocks, resulting in 280 children in the CB groupand 283 in the PB group [15] [16] [20] [21] [25]-[29]. Two of the nine RCTs reported equal rates of vomiting, three RCTs reported increased vomiting after PB, and four RCTs reported increased vomiting after CB. One RCT with increased vomiting after CB reached statistical significance [28]. There was no significant heterogeneity between trials $\left(p=0.329, \mathrm{I}^{2}=12.7\right)$ and a fixed-effects model was used. Meta-analysis demonstrated no difference in the RR for vomiting between $\mathrm{CB}$ and $\mathrm{PB}(\mathrm{RR}=1.56,95 \% \mathrm{CI}=$ 0.91 to $2.67 ; p=0.107$ ).

\subsection{Length of Stay Following CB or PB during Circumcision}

Length of stay was reported in two of the nine trials involving 80 children in each group [16] [28]. Both studies reported longer length of stay after CB, however only one reached statistical significance. There was significant

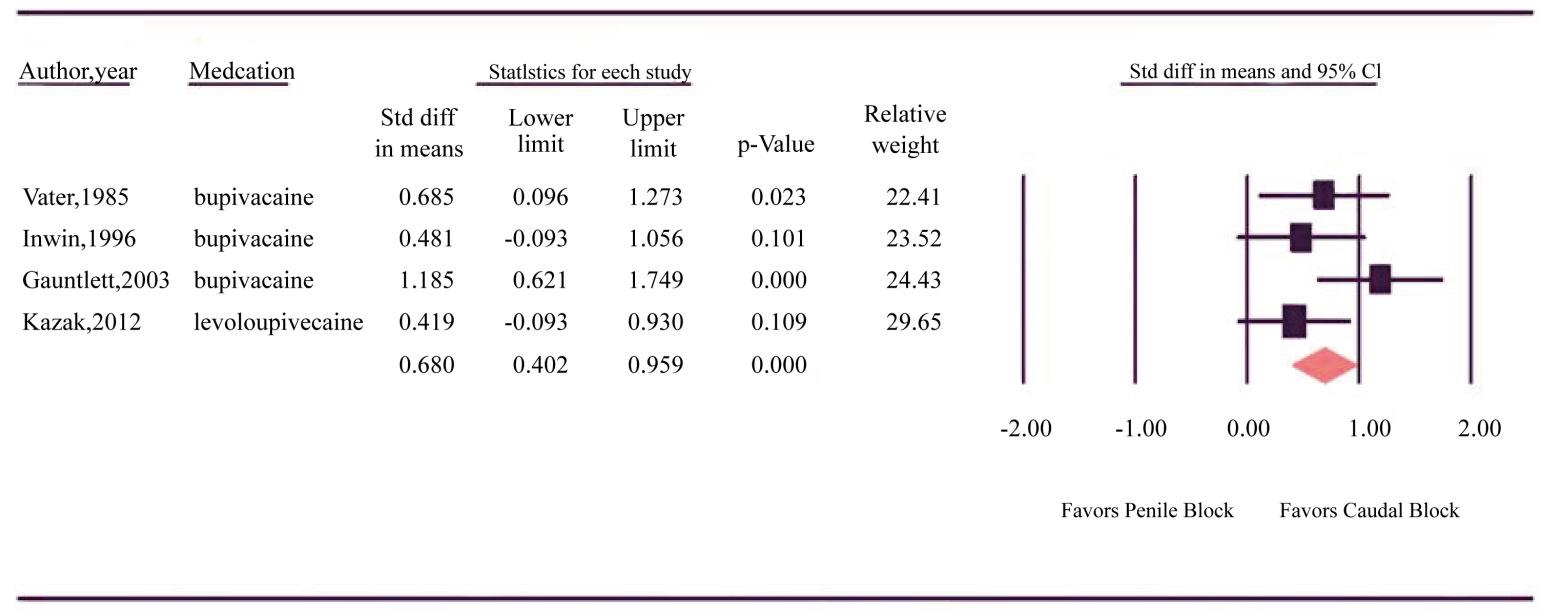

Abbreviation:CI,confidence interval; diff,difference;Std, standard.

Figure 4. Forest plot evaluating the standardized difference in mean for time to first micturition with caudal and penile block in circumcision. 


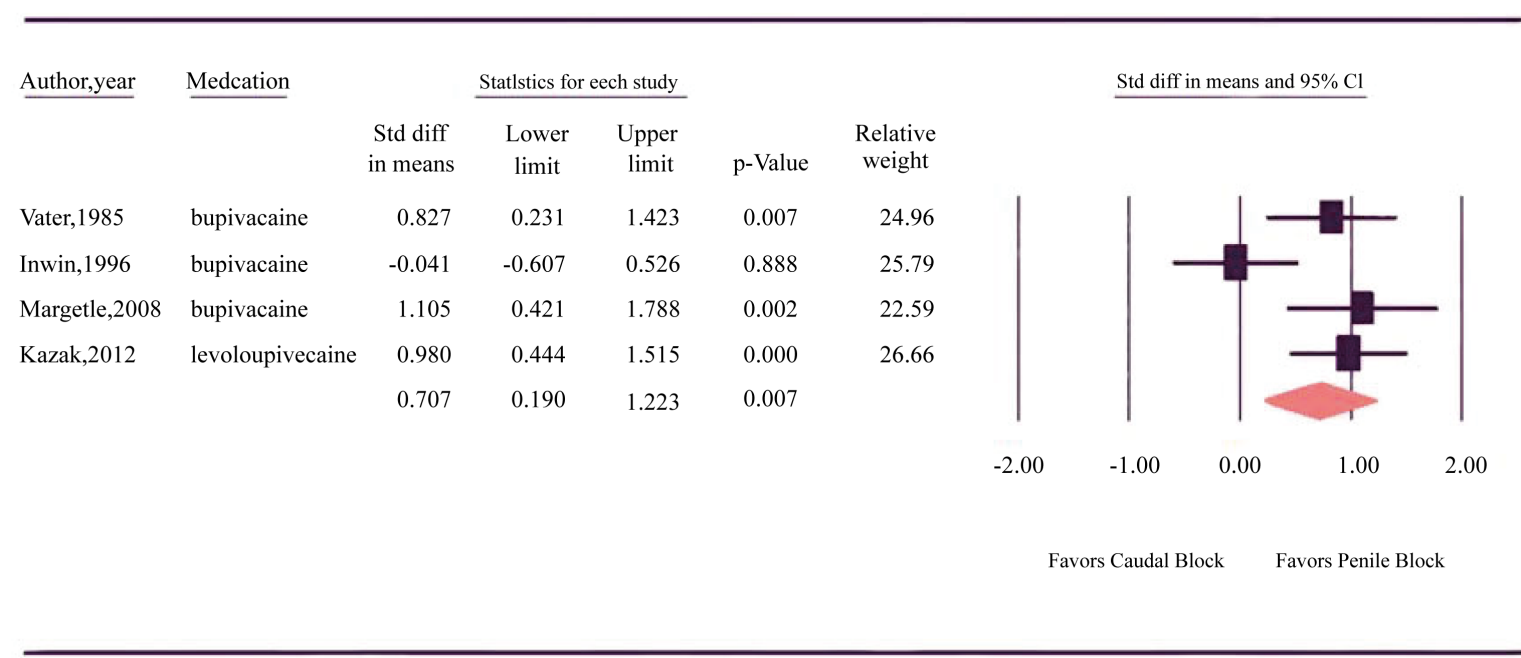

Abbreviation:CI,confidence interval; diff,difference;Std, standard.

Figure 5. Forest plot evaluating the standardized difference in mean for the duration of motor block with caudal and penile block in circumcision.

heterogeneity between trials $\left(p=0.017, \mathrm{I}^{2}=82.532\right)$ and a random-effects model was assumed. Meta-analysis revealed no difference in mean length of stay between CB and PB (SDM $=0.741,95 \%$ CI $=-0.05$ to $1.53 ; p=$ 0.066).

\subsection{Subgroup Analysis Based on Medication}

No differencewas observed in regards to bupivacaine or levobupivacainerelated efficacy ( $p=0.418$ ), time to first additive analgesia ( $p=0.528$ ), time to first micturition $(p=0.272$ ), duration of prolonged motor blockade $(p=0.409)$ and risk of vomiting $(p=0.752)$.

\subsection{Publication Bias}

A funnel plot was used to visually assess for publication bias and both Egger's and Begg's tests were performed to calculate publication bias (Figure 6). There was no qualitative evidence of asymmetry on the funnel plots. Egger's and Begg's tests also revealed no evidence of quantitative publication bias as the lowest $p$-value noted was 0.173 and 0.293 , respectively.

\section{Discussion}

Secular circumcision is a common practice in the United States and is associated with decreased sexually transmitted infections and urinary tract infections [5]. The personal medical benefits are reflected in large prevalence of the procedure. In 2012, the Agency for Healthcare Research and Qualityreported that hospitalization for circumcision was performed 13.9 times more often than the second most common pediatric surgery, appendectomy [30]. Despite the high prevalence rates of circumcision, perioperative pain management remains a major concern, as a variety of analgesics has rendered the determination of a superior anesthetic difficult [18] [21] [26] [28] [31]-[36].

Analgesic techniques in circumcision include oral sucrose, topical anesthetic, systemic non-steroidal anti-inflammatory drugs (NSAIDs) or opioids, and regional anesthesia [18] [33]-[36]. Non-pharmacological interventions like oral sucrose reduce the duration of cry during circumcisionin children less than oneyear, butappear suboptimal to other anesthetics, as solitary use of oral sucrose isinsufficient in treating surgical pain [33]-[37]. Regional anesthetics, in comparison to topical anesthetic and systemic NSAIDs and opioids, offer more optimal pain control with fewer side effects of somnolence, respiratory depression, emesis, and ileus [18] [28] [38]. A one year prospective survey involving 24,409 children reported no long term complications in children less than 
Funnel Plot of Standard Error by Log risk ratio

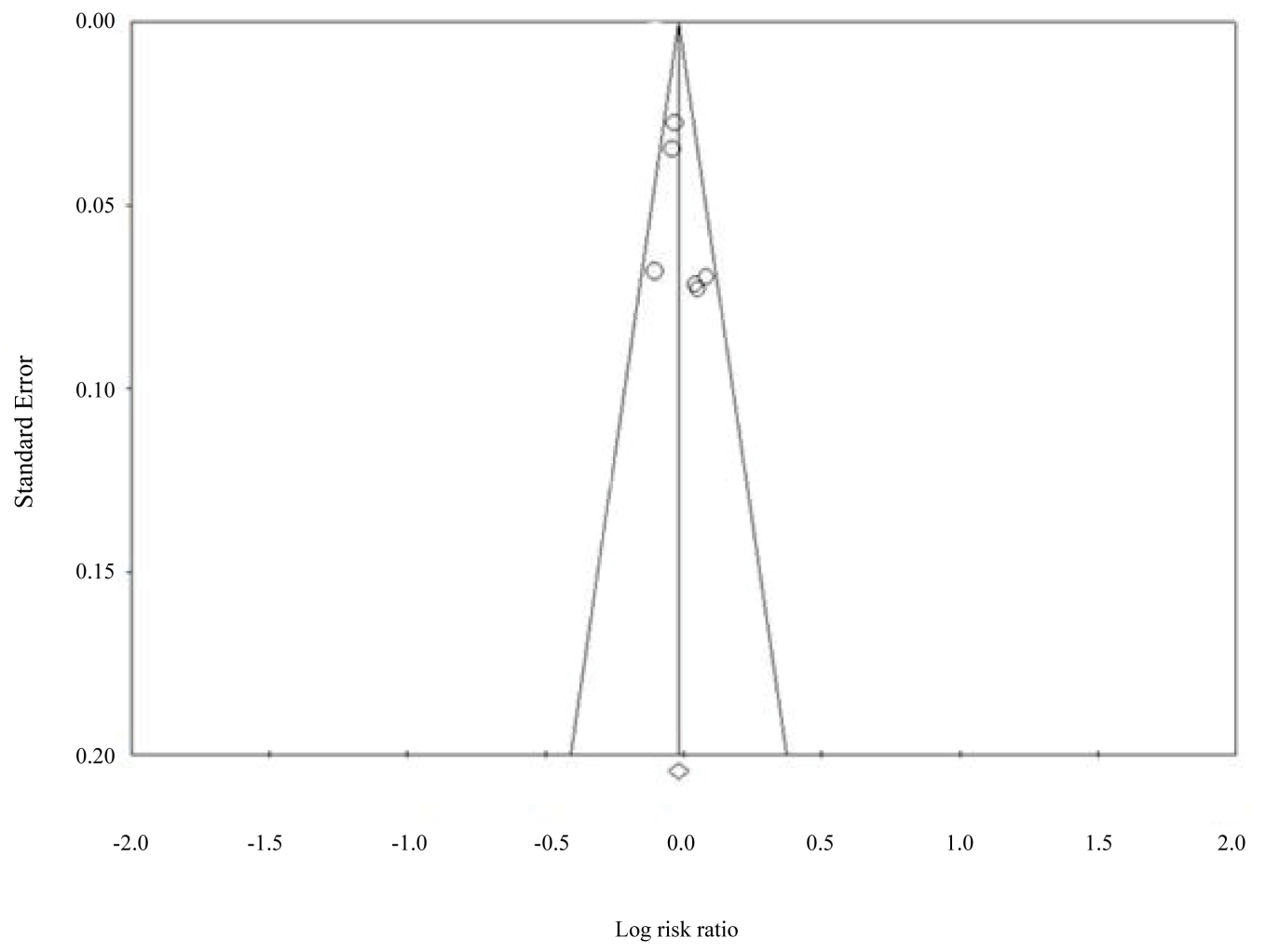

Figure 6. Funnel plot of the included studies.

three years and recommended the use of regional anesthesia (overall rate of complication $=0.12 \%, 95 \% \mathrm{CI}=$ 0.09 to 0.17 ) [39]. Despite these advancements, the reliability, effectiveness, and safety of CB to PB in circumcision remains controversial [15] [20].

PB provides analgesia over 3/4 of the dorsal penis, while CBprovides complete penile analgesia [17] [27] [29] [31] [40]-[42]. Pain studies have demonstrated longer analgesic duration after CB though this meta-analysis of 9 RCTs $(\mathrm{N}=574)$ failed to demonstrate statistical differences in the efficacy and duration of first additive analgesia. These results are consistent with a prior Cochrane systematic review (2008) involving 4 RCTs $(\mathrm{N}=336)$, as the study also failed to reveal any difference in the efficacy or need for rescue analgesia between CB and PB $(\mathrm{RR}=1.25,95 \% \mathrm{CI}=0.64$ to 2.44, $p=0.52)$ [22]. A RCT of 104 patients by Haliloglu et al. (2013) reported a higherpain score in children postoperatively following PB at 30 minutes but not at 60 minutes (30 minutes: $p<$ 0.001 and at 60 minutes: $p=0.189$ ) [1]. These results suggest any difference in analgesia after PB and CB wanes quickly after the first half hour of administration.

Analgesic effectsin circumcision are varied when bupivacaine and its isomers, levobupivacaine and ropivacaine, are compared. Kaya et al. (2012) studied 60 CB patients receiving bupivacaine orlevobupivacaine and found bupivacaine enabled longer analgesic effects compared to levobupivacaine $(p<0.001)$ [31] [40]. In contrast, Locatelli et al. (2005) studied 99 CB patients comparing all three bupivacaine isomers and reported no difference in analgesic efficacy ( $p=0.37$ ) [40]. Subgroup analysis for bupivacaine and levobupivacaine in this meta-analysis revealed no difference in the measured outcomes, suggesting the use of either isomer is suitable.

CB's analgesic efficiency can also be improved in concert with adjuvant drugs such as ketamine and magnesium. Lonnqvist (2010) reported the use of adjuvant drugs with CB improved analgesic effects up to 24 hours [17]. Kim et al. (2014) demonstrated time to first additive analgesia, proportion of patients requiring analgesia postoperatively within 24 hours, and amount of postoperative analgesia were all influenced positively when adjunctive drugs were used with CB [42].

In comparison to $\mathrm{PB}, \mathrm{CB}$ is associated with increased risk of short term complications including urinary re- 
tention and delayed ambulation due to the inhibition ofboth the sacral parasympathetic and the somatic conduction [20] [21]. Bupivacaine is associated with dose dependent duration of motor blockade [31] [40] [43] [44]. An observational study by Silvani et al. (2006) involving 30 children receiving CB with low concentrationsof bupivacaine prolonged analgesia while shortening the duration of motor block (low volume, high concentration analgesic duration: $520 \pm 480 \mathrm{~min}$; high volume, low concentration analgesic duration: $952 \pm 506 \mathrm{~min}, p<0.05$ ) [18] [45]. Optimal anesthetic dose may increase analgesic efficacy after CB while limiting the duration of motor block.

Although the results of this meta-analysis were significant, there are limitations to the study due to the variation and heterogeneity of the RCTs included. The anesthetic type, dose, and adjuvant used varied between studies. The enrollment criteria used in each study differedin regards to age. None of the studies included children less than 18 months,thus reducing the generalizability of these results. The paucity of RCTs in the neonatal population is secondary to the difficulty in pain assessment among newborns, as well as studies associating seizures and arrhythmias to regional anesthesia [17] [39] [46]. That said, more recent studies have documentedreport neonatal complication ratesof less than 1/1000 with no long term effects, thereby warranting increased use of CB and PB in this [17] [39] [46].

\section{Conclusion}

In conclusion, $\mathrm{CB}$ and $\mathrm{PB}$ regional anesthesia performed during circumcision yielded similar success rates in children aged 18 months to 16 years. CB demonstrated a trend towards longer analgesic duration with significantly more urinary retention and a longer motor block. Results of this meta-analysis suggest CB is apreferred technique compared to PB in non-ambulatory children, as the delayed micturition and ambulation do not significantly impact the length of stay. In ambulatory children, PB should be used over CB to allow for earlier mobility and comfort for the circumcised child. Additional research into bupivacaine isomers and adjuvants should be conducted to determine optimal anesthetic type and dose for pediatric circumcisions, thereby increasing analgesic proficiency while decreasing potential complications.

\section{References}

[1] Haliloglu, A.H., Gokce, M.I., Tangal, S., Boga, M.S., Tapar, H. and Aladag, E. (2013) Comparison of Postoperative Analgesic Efficacy of Penile Block, Caudal Block and Intravenous Paracetamol for Circumcision: A Prospective Randomized Study. Anaesthesia, 39, 862-866. http://dx.doi.org/10.1590/s1677-5538.ibju.2013.04.13

[2] Bellieni, C.V., Alagna, M.G. and Buonocore, G. (2013) Analgesia for Infants' Circumcision. Italian Journal of Pediatrics, 39. http://dx.doi.org/10.1186/1824-7288-39-38

[3] World Health Organization, Joint United Nations (2007) Male Circumcision: Global Trends and Determinants of Prevalence, Safety and Acceptability. WHO Press, Geneva.

[4] Baskin, L.S. (2015) Neonatal Circumcision: Risks and Benefits. UpToDate, Waltham.

[5] Morris, B.J., Bailis, S.A. and Wiswell, T.E. (2014) Circumcision Rates in the United States: Rising or Falling? What Effect Might the New Affirmative Ediatric Policy Statement Have? Mayo Clinic Proceedings, 89, 677-686. http://dx.doi.org/10.1016/j.mayocp.2014.01.001

[6] Owings, M., Uddin, S. and Williams, S. (2013) Trends in Circumcision for Male Newborns in US Hospitals $1979-2010$. National Center for Health Statistics.

[7] Blank, S., Brady, M., Buerk, E., et al. (2012) Male Circumcision. Pediatrics, 130, 756-785. http://dx.doi.org/10.1542/peds.2012-1990

[8] Taylor, J., Lockwood, A. and Taylor, A. (1996) The Prepuce: Specialized Mucosa of the Penis and Its Loss to Circumcision. British Journal of Urology, 77, 291-295. http://dx.doi.org/10.1046/j.1464-410X.1996.85023.X

[9] Bronselaer, G., Schober, J., Meyer-Bahlburg, H., T’Sjoen, G., Vlietinck, R. and Hoebeke, P. (2013) Male Circumcision Decreases Penile Sensitivity as Measured in a Large Cohort. BJU International, 111, 820-827. http://dx.doi.org/10.1111/j.1464-410X.2012.11761.x

[10] Morris, B.J. and Krieger, J.N. (2013) Does Male Circumcision Affect Sexual Function, Sensitivity, or Satisfaction?-A Systematic Review. The Journal of Sexual Medicine, 10, 2644-2657. http://dx.doi.org/10.1111/jsm.12293

[11] Maitra, S., Baidya, D.K., Pawar, D.K., Arora, M.K. and Khanna, P. (2014) Epidural Anesthesia and Analgesia in the Neonate: A Review of Current Evidences. Journal of Anesthesia, 28, 768-779. http://dx.doi.org/10.1007/s00540-014-1796-8 
[12] Peters, J., Schouw, R., Anand, K., Van Dijk, M., Duivenvoorden, H. and Tibboel. D. (2005) Does Neonatal Surgery Lead to Increased Pain Sensitivity in Later Childhood? Pain, 114, 444-454. http://dx.doi.org/10.1016/j.pain.2005.01.014

[13] Taddio, A. and Katz, J. (2005) The Effects of Early Pain Experience in Neonates on Pain Responses in Infancy and Childhood. Pediatric Drugs, 7, 245-257. http://dx.doi.org/10.2165/00148581-200507040-00004

[14] Taddio, A., Katz, J., Ilersich, A.L. and Koren, G. (1997) Effect of Neonatal Circumcision on Pain Response during Subsequent Routine Vaccination. The Lancet, 349, 599-603. http://dx.doi.org/10.1016/S0140-6736(96)10316-0

[15] Beyaz, S.G. (2011) Comparison of Postoperative Analgesic Efficacy of Caudal Block versus Dorsal Penile Nerve Block with Levobupivacaine for Circumcision in Children. The Korean Journal of Pain, 24, 31-35. http://dx.doi.org/10.3344/kjp.2011.24.1.31

[16] Bengisun, Z.K., Ekmekci, P. and Haliloglu, A.H. (2012) Levobupivacaine for Postoperative Pain Management in Circumcision: Caudal Blocks or Dorsal Penile Nerve Block. The Journal of the Turkish Society of Algology, 24, 180-186. http://dx.doi.org/10.5505/agri.2012.21931

[17] Lönnqvist, P.A. (2010) Regional Anaesthesia and Analgesia in the Neonate. Best Practice and Research Clinical Anaesthesiology, 24, 309-321. http://dx.doi.org/10.1016/j.bpa.2010.02.012

[18] Shanthanna, H., Singh, B. and Guyatt, G. (2014) A Systematic Review and Meta-Analysis of Caudal Block as Compared to Noncaudal Regional Techniques for Inguinal Surgeries in Children. BioMed Research International, 2014, Article ID: 890626.

[19] Chhibber, A.K., Perkins, F.M., Rabinowitz, R., Vogt, A.W. and Hulbert, W.C. (1997) Penile Block Timing for Postoperative Analgesia of Hypospadias Repair in Children. The Journal of Urology, 158, 1156-1159. http://dx.doi.org/10.1016/S0022-5347(01)64410-0

[20] Irwin, M.G. and Cheng, W. (1996) Comparison of Subcutaneous Ring Block of the Penis with Caudal Epidural Block for Post-Circumcision Analgesia in Children. Anaesthesia and Intensive Care, 24, 365-367.

[21] Vater, M. and Wandless, J. (1985) Caudal or Dorsal Nerve Block? A Comparison of Two Local Anaesthetic Techniques for Postoperative Analgesia Following Day Case Circumcision. Acta Anaesthesiologica Scandinavica, 29, 175-179. http://dx.doi.org/10.1111/j.1399-6576.1985.tb02180.x

[22] Cyna, A.M. and Middleton, P. (2008) Caudal Epidural Block versus Other Methods of Postoperative Pain Relief for Circumcision in Boys. Cochrane Database of Systematic Reviews, 8, CD003005. http://dx.doi.org/10.1002/14651858.cd003005.pub2

[23] Hozo, S.P., Djulbegovic, B. and Hozo, I. (2005) Estimating the Mean and Variance from the Median, Range, and the Size of a Sample. BMC Medical Research Methodology, 5, 13.

[24] Bland, M. (2015) Estimating Mean and Standard Deviation from the Sample Size, Three Quartiles, Minimum, and Maximum. International Journal of Statistics in Medical Research, 4, 57-64. http://dx.doi.org/10.6000/1929-6029.2015.04.01.6

[25] Yeoman, P.M., Cooke, R. and Hain, W.R. (1983) Penile Block for Circumcision? A Comparison with Caudal Blockade. Anaesthesia, 38, 862-866. http://dx.doi.org/10.1111/j.1365-2044.1983.tb12251.x

[26] Mak, M.Y., Philip, A.E., Cho, S.-C. and Chan, J.T.-M. (2001) Postoperative Analgesia in Children Day Surgery Circumcision: Comparison of Three Methods. Annals of the College of Surgeons Hong Kong, 5, 146-150. http://dx.doi.org/10.1046/j.1442-2034.2001.00114.x

[27] Gauntlett, I. (2003) A Comparison between Local Anaesthetic Dorsal Nerve Block and Caudal Bupivacaine with Ketamine for Paediatric Circumcision. Paediatric Anaesthesia, 13, 38-42. http://dx.doi.org/10.1046/j.1460-9592.2003.00926.x

[28] Weksler, N., Atias, I., Klein, M., Rosenztsveig, V., Ovadia, L. and Gurman, G.M. (2005) Is Penile Block Better than Caudal Epidural Block for Postcircumcision Analgesia? Journal of Anesthesia, 19, 36-39. http://dx.doi.org/10.1007/s00540-004-0287-8

[29] Margetts, L., Carr, A., McFadyen, G. and Lambert, A. (2008) A Comparison of Caudal Bupivacaine and Ketamine with Penile Block for Paediatric Circumcision. European Journal of Anaesthesiology, 25, 1009-1013. http://dx.doi.org/10.1017/S0265021508004833

[30] Witt, W.P., Weiss, A.J. and Elixhauser, A. (2014) Overview of Hospital Stays for Children in the United States, 2012. Agency for Healthcare Research and Quality, Rockville.

[31] Kaya, Z., Feridun, M., Arici, S., Karaman, S., Tapar, H. and Erdemir, F. (2012) Prospective, Randomized, DoubleBlinded Comparison of the Effects of Caudally Administered Levobupivacaine $0.25 \%$ and Bupivacaine $0.25 \%$ on Pain and Motor Block in Children Undergoing Circumcision Surgery. European Review for Medical and Pharmacological Sciences, 16, 2014-2020. 
[32] Denniston, G.C., Hodges, F.M. and Milos, M.F., Eds. (2013) Genital Cutting: Protecting Children from Medical, Cultural and Religious Infringements. Springer, Dordrecht, 58. http://dx.doi.org/10.1007/978-94-007-6407-1

[33] Lander, J., Brady-Fryer, B., Metcalfe, J.B., Nazarali, S. and Muttitt, S. (1997) Comparison of Ring Block, Dorsal Penile Nerve Block, and Topical Anesthesia for Neonatal Circumcision: A Randomized Controlled Trial. JAMA, 278, 2157-2162. http://dx.doi.org/10.1001/jama.1997.03550240047032

[34] Chambers, F.A., Lee, J., Smith, J. and Casey, W. (1994) Post-Circumcision Analgesia: Comparison of Topical Analgesia with Dorsal Nerve Block Using the Midline and Lateral Approaches. British Journal of Anaesthesia, 73, 437-439. http://dx.doi.org/10.1093/bja/73.4.437

[35] Al Qahtani, R., Abu-Salem, L.Y. and Pal, K. (2014) Effect of Lidocaine-Prilocaine Eutectic Mixture of Local Anaesthetic Cream Compared with Oral Sucrose or both in Alleviating Pain in Neonatal Circumcision Procedure. African Journal of Paediatric Surgery, 11, 56-61. http://dx.doi.org/10.4103/0189-6725.129236

[36] Kassab, M., Foster, J.P., Foureur, M. and Fowler, C. (2012) Sweet-Tasting Solutions for Needle-Related Procedural Pain in Infants One Month to One Year of Age. The Cochrane Dataase of Systematic Reviews, 12, CD008411.

[37] Ward, R.M., Stiers, J. and Buchi, K. (2015) Neonatal Medications. Pediatric Clinics of North America, 62, 525-544. http://dx.doi.org/10.1016/j.pcl.2014.11.012

[38] Lunn, J.N. (1979) Postoperative Analgesia after Circumcision. A Randomized Comparison between Caudal Analgesia and Intramuscular Morphine in Boys. Anaesthesia, 34, 552-524. http://dx.doi.org/10.1111/j.1365-2044.1979.tb06340.x

[39] Giaufre, E., Dalens, B. and Gombert, A. (1996) Epidemiology and Morbidity of Regional Anesthesia in Children: A One-Year Prospective Survey of the French-Language Society of Pediatric Anesthesiologists. Anesthesia and Analgesia, 83, 904-912.

[40] Locatelli, B., Ingelmo, P., Sonzogni ,V., et al. (2005) Randomized, Double-Blind, Phase III, Controlled Trial Comparing Levobupivacaine $0.25 \%$, Ropivacaine $0.25 \%$ and Bupivacaine $0.25 \%$ by the Caudal Route in Children. British Journal of Anaesthesia, 94, 366-371. http://dx.doi.org/10.1093/bja/aei059

[41] Cook, B., Grubb, D.J., Aldridge, L.A. and Doyle, E. (1995) Comparison of the Effects of Adrenaline, Clonidine and Ketamine on the Duration of Caudal Analgesia Produced by Bupivacaine in Children. British Journal of Anaesthesia, 75, 698-701. http://dx.doi.org/10.1093/bja/75.6.698

[42] Kim, E.M., Kim, M.-S., Han, S.-J., et al. (2014) Magnesium as an Adjuvant for Caudal Analgesia in Children. Pediatric Anesthesia, 24, 1231-1238. http://dx.doi.org/10.1111/pan.12559

[43] Dobereiner, E.F., Cox, R.G., Ewen, A. and Lardner, D.R. (2010) Evidence-Based Clinical Update: Which Local Anesthetic Drug for Pediatric Caudal Block Provides Optimal Efficacy with the Fewest Side Effects? Canadian Journal of Anaesthesia, 57, 1102-1110. http://dx.doi.org/10.1007/s12630-010-9386-1

[44] Wolf, A.R., Valley, R.D., Fear, D.W., Roy, W.L. and Lerman, J. (1988) Bupivacaine for Caudal Analgesia in Infants and Children: The Optimal Effective Concentration. Anesthesiology, 69, 102-106. http://dx.doi.org/10.1097/00000542-198807000-00017

[45] Silvani, P., Camporesi, A., Agostino, M.R. and Salvo, I. (2006) Caudal Anesthesia in Pediatrics: An Update. Minerva Anestesiologica, 72, 453-459.

[46] Berde, C.B. (1993) Toxicity of Local Anesthetics in Infants and Children. The Journal of Pediatrics, 122, S14-S20. 